\title{
Tobacco smoke and nicotine suppress expression of activating signaling molecules in human dendritic cells
}

Nuha Alkhattabi ${ }^{12}$, Ian Todd', Ola Negm³, Patrick J Tighe, Lucy C Fairclough*

School of Life Sciences, University of Nottingham, Nottingham, UK

Joint first authors

\section{Current address:}

${ }^{2}$ Department of Biochemistry, King Abdulaziz University, Jeddah, Kingdom of Saudi Arabia ${ }^{3}$ School of Medicine, University of Nottingham, Nottingham, United Kingdom

*Corresponding author at: School of Life Sciences, University of Nottingham, Life Sciences Building, University Park, Nottingham, NG7 2RD, United Kingdom

E-mail address: lucy.fairclough@nottingham.ac.uk (L.C. Fairclough)

Running title: Tobacco suppression of DC signalome 


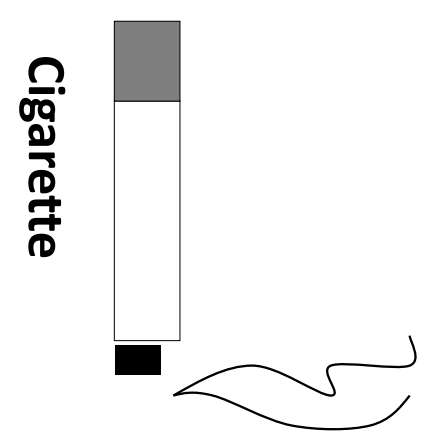

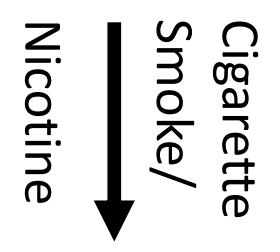

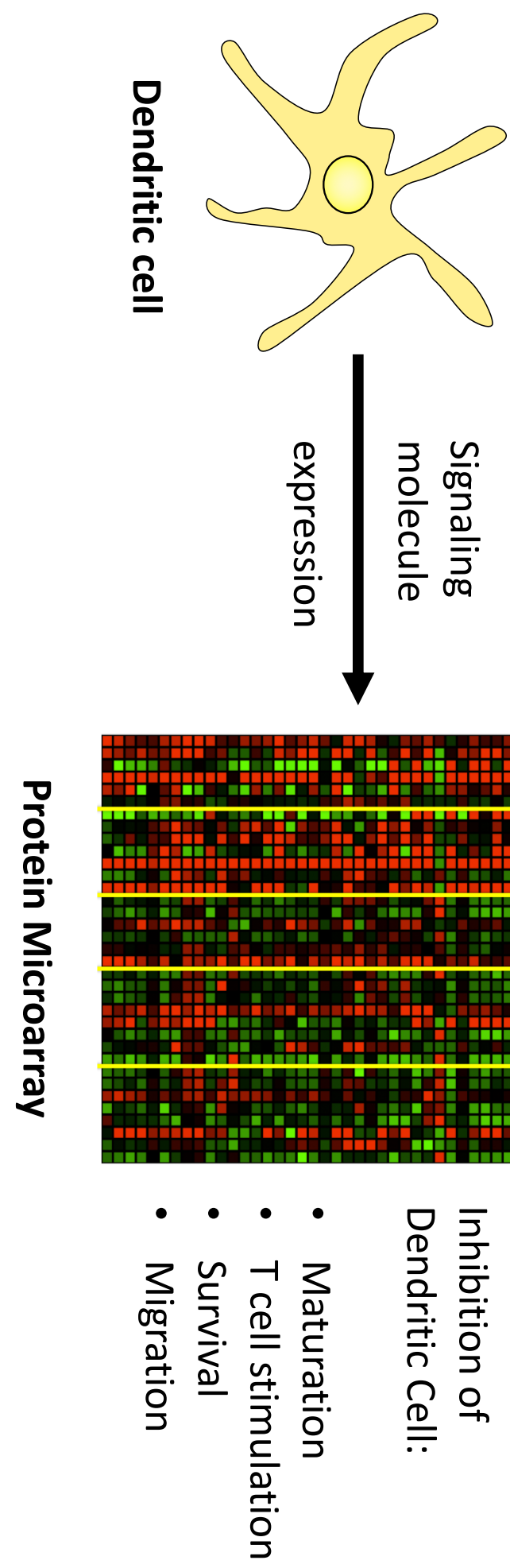




\begin{abstract}
Cigarette smoke has significant toxic effects on the immune system, and increases the risk of developing autoimmune diseases; one immunosuppressive effect of cigarette smoke is that it inhibits the T cell-stimulating, immunogenic properties of myeloid dendritic cells (DCs). As the functions of DCs are regulated by intra-cellular signaling pathways, we investigated the effects of cigarette smoke extract (CSE) and nicotine on multiple signaling molecules and other regulatory proteins in human DCs to elucidate the molecular basis of the inhibition of DC maturation and function by CSE and nicotine. Maturation of monocyte-derived DCs was induced with the TLR3-agonist poly I:C or with the TLR4-agonist lipopolysaccharide, in the absence or presence of CSE or nicotine. Reverse-phase protein microarray was used to quantify multiple signaling molecules and other proteins in cell lysates. Particularly in poly I:C-matured DCs, cigarette smoke constituents and nicotine suppressed the expression of signaling molecules associated with DC maturation and $\mathrm{T}$ cell stimulation, cell survival and cell migration. In conclusion, constituents of tobacco smoke suppress the immunogenic potential of DCs at the signaling pathway level.
\end{abstract}

Keywords: Dendritic cell; tobacco smoke; nicotine; protein array; signalome; autoimmunity 


\section{Introduction}

Myeloid dendritic cells (mDCs) are pivotal in maintenance of self-tolerance and induction of autoimmunity $[1,2]$. Activated mDCs upregulate MHC molecules and costimulatory proteins like CD80/CD86, and stimulate activation of naïve T cells $[3,4]$. Immature, 'steady state', mDCs express little CD80/86 and induce Th/Tc anergy and Treg activation $[1,5]$.

The phenotype and functions of mDCs are affected by tobacco smoke, with suppression of T cell-stimulating, immunogenic properties of mDCs by CS constituents [6]. Evidence for this derives from human and murine in vivo and in vitro studies. In a mouse smoking model, DCs show low expression of co-stimulatory molecules and reduced stimulation T cells $[7,8]$. Similarly, in humans, smoking impairs the maturation of mDCs in the lungs, evidenced by reduced expression of CD40, CD83 and CCR7 [9, 10]. Treatment of mouse bone marrow-derived DCs (bmDCs) with cigarette smoke extract (CSE) differentially affects $\mathrm{T}$ cell stimulation, depending on $\mathrm{T}$ cell phenotype (CD4+ ${ }^{+}$or $\left.\mathrm{CD} 8^{+}\right)$[11] and length of treatment (chronic exposure to CSE suppresses DC maturation) [12]. The maturation of human monocyte-derived DCs (moDCs), and their ability to stimulate Th1 and Th17 cells, is also suppressed by CSE [13-15]. Although numerous chemicals within CS affect immune cells [6], nicotine is the main addictive component and has well-documented suppressive effects on IL-12 production and Th1 stimulation by human moDCs and mouse bmDCs, promoting instead Th2 responses [16-19]. Immunosuppressive effects of nicotine are exerted particularly via the $\alpha 7$ nicotinic acetylcholine receptor [20].

The differentiation, regulation and functions of DCs, as with all cells, is dependent on intra-cellular signaling pathways. The aim of the present study was to investigate the effects of CSE and nicotine on signaling pathways in human moDCs as this would enhance understanding the effects of tobacco constituents on DCs, and the association between smoking and autoimmunity. This was achieved by reverse-phase protein microarray (RPPA) to quantify multiple signaling molecules in small volumes of cell lysates using highly specific antibodies. We previously used RPPA to demonstrate constitutive activation of multiple proinflammatory signaling pathways in an autoinflammatory disease [21]. Here, we demonstrate down-regulation of signaling pathways and other proteins in moDCs by CSE and nicotine that is consistent with inhibition of DC maturation, survival and migration. 


\section{Materials and methods}

\subsection{Isolation of peripheral blood mononuclear cells (PBMCs)}

Blood samples were collected from healthy volunteers with informed consent (University of Nottingham Medical School Ethics Committee; BT 15/03/2010). Buffy coats and leucocytes cones from anonymized healthy donors were from the Regional Blood Transfusion Service (Sheffield, UK). PBMCs were separated by density gradient centrifugation using Histopaque1077 (Sigma-Aldrich). The cells were washed and resuspended in RPMI complete medium, i.e. RPMI-1640 medium (Sigma-Aldrich) supplemented with 10mM HEPES, $100 \mathrm{IU} / \mathrm{ml}$ penicillin, $100 \mu \mathrm{g} / \mathrm{ml}$ streptomycin, $2 \mathrm{mM}$ L-glutamine (Sigma-Aldrich) and 10\% fetal bovine serum (FBS).

\subsection{Isolation of $C D 14^{+}$monocytes}

CD14+ monocytes were isolated from PBMCs using CD14+ microbeads (Miltenyi Biotec, Surrey, UK) by positive selection (manufacturer's protocol). The separated cells were resuspended in RPMI complete medium and their purity was checkedby flow cytometry (Beckman-Coulter FC500) following staining with anti-CD14-FITC (Beckman-Coulter). Fresh blood, buffy coats and leucocyte cones yielded CD14+ monocytes with 84\%-93\% purity.

\subsection{Generation and phenotyping of immature and mature moDCs}

To generate immature moDCs, CD14+cells were cultured at $5 \times 10^{s}$ cells $/ \mathrm{ml}$ in RPMI complete medium supplemented with 50ng/ml GM-CSF and 20ng/ml IL-4 (R\&D Systems) at $37^{\circ} \mathrm{C}$, $5 \% \mathrm{CO}_{2}$ for five days; $500 \mu \mathrm{l}$ of fresh medium and cytokines were added on day three. To generate mature moDCs, day five immature moDCs were stimulated with $100 \mathrm{ng} / \mathrm{ml}$ LPS (Sigma-Aldrich, Cat. No. L4391) or 30 $\mathrm{gg} / \mathrm{ml}$ poly I:C (InvivoGen) and incubated at $37^{\circ} \mathrm{C}$, $5 \% \mathrm{CO}_{2}$ for $24 \mathrm{~h}$. Staining for flow cytometry was performed essentially as described previously [22]; details are given in Supplementary table 1.

Detection of cytokines secreted by immature and mature dendritic cells was performed by protein micro-array, as previously described [23], using reagents from $R \& D$ Systems DuoSet kits specific for the following human cytokines: IL-12 (DY1270), IL-10 (DY217B), IL-8 (DY208), IL-6 (DY206) and TNF- $\alpha$ (DY210). 


\subsection{Cigarette smoke extract (CSE) preparation}

The procedure for generating CSE was based on that used in previous studies [24-31]. Smoke generated from the combustion of a Marlboro Red cigarette (without filter, consistent with previous studies [24, 26-29], to ensure that all potential toxicants were present in the extract) was bubbled into phenol red-free RPMI medium (Sigma-Aldrich). The medium was then filtered through a $0.45 \mu \mathrm{m}$ filter and a dilution series of the CSE was prepared and absorbances measured using a Nanodrop ND-1000 spectrophotometer. The dilution required to obtain an absorbance of 0.15 was calculated; the resulting extract was designated $100 \%$ CSE. A concentration range of 0.5\%-3\% CSE was used to treat moDCs, consistent with previous studies of the effects of CSE on cells in vitro [24, 27, 28, 30, 31].

\subsection{Treatment of moDCs with CSE or nicotine}

Day five immature moDCs were cultured for $24 \mathrm{~h}$ with or without $100 \mathrm{ng} / \mathrm{ml} \mathrm{LPS} \mathrm{or} 30 \mu \mathrm{g} / \mathrm{ml}$ polyI:C in the absence, or presence, of $0.5 \% \mathrm{CSE}, 3 \% \mathrm{CSE}, 12 \mu \mathrm{g} / \mathrm{ml}(-)$-nicotine or $200 \mu \mathrm{g} / \mathrm{ml}(-)$-nicotine (Sigma-Aldrich). The chosen nicotine concentrations were based on $12 \mu \mathrm{g}$ representing approximately $1 \%$ of the nicotine inhaled per cigarette (i.e. about $1.2 \mathrm{mg}$ per cigarette [32]) and 200 $\mu \mathrm{g}$ representing approximately $1 \%$ of the nicotine inhaled by smoking 15-20 cigarettes per day [32]; these concentrations were also consistent with those used in previous studies [31,33-35]. The treatments with CSE and nicotine had no significant effect on cell viability, as determined by flow cytometry (data not shown).

\subsection{Preparation of moDC lysates and RPPA processing}

The treated cells were harvested and washed in ice-cold PBS. RIPA buffer (ThermoScientific) supplemented with a 1:10 dilution of phosphate/protease inhibitor (ThermoScientific) was added to the cells ( $1 \mathrm{ml}$ buffer per $5 \times 10^{\circ}$ cells). The cells and buffer were mixed and the tubes were incubated on ice for $30 \mathrm{~min}$. The samples were then centrifuged at $14,000 \mathrm{~g}, 4^{\circ} \mathrm{C}$ for $15 \mathrm{~min}$. The supernatants were stored at $-80^{\circ} \mathrm{C}$. RPPA was performed essentially as described previously [21]; details are given in Supplementary table 2. We previously validated the RPPA by showing strong correlation between results obtained by RPPA and conventional immunoblotting for detection of signaling molecules [21]. Samples that did not generate array features that conformed to stringent validation criteria (e.g. uniform shape and pixel density; signal to background ratio) were excluded from the analysis. 


\subsection{Statistical analysis}

Data for expression of CD markers and secreted cytokine concentrations were compared by Wilcoxon matched-pairs test. The RPPA data passed the Kolmogorov-Smirnov test for normality and are presented with the means in scatter plots. Each individual reading is the mean of three replicates. One-way ANOVA was applied followed by Dunnett's multiple comparison test; $\mathrm{p} \leq 0.05$ was considered significant.

\section{Results}

\subsection{Effects of DC maturation on expression of CD markers, cytokines and signaling molecules}

Immature, monocyte-derived DCs (moDCs) were generated from PBMCs of healthy human donors and maturation was induced by treatment with $100 \mathrm{ng} / \mathrm{ml}$ lipopolysaccharide (LPS) or $30 \mu \mathrm{g} / \mathrm{ml}$ poly I:C for $24 \mathrm{~h}$. The effectiveness of LPS and polyI:C in inducing the maturation of moDCs is demonstrated in figure 1, which shows that these TLR agonists induced increased expression of CD-80, CD-86 and CD-83 (figure 1(i)), and secretion of IL-12, IL10, IL-8, IL-6 and TNF- $\alpha$ (figure 1(ii)).

In addition, lysates of the immature, polyI:C and LPS treated moDCs were screened by RPPA for expression of 39 signaling molecules and other proteins associated with DC phenotype and functions. The heat map of protein expression in the lysates (figure 1(iii)) shows that induction of DC maturation with LPS (centre columns) or poly I:C (right-hand columns) broadly upregulated expression of the protein molecules examined compared to their expression in immature DCs (left-hand columns).

\subsection{Effects of CSE and nicotine on moDCs}

Culturing immature moDCs with CSE $(1 \%$ or $3 \%)$ or nicotine $(12 \mu \mathrm{g} / \mathrm{ml}$ or $200 \mu \mathrm{g} / \mathrm{ml})$ resulted in significant downregulation in expression of TNFL6, PIP5K1C, CXCR4, SOD1 and MYD88, particularly by nicotine (Supplementary figure 1). Culturing LPS-matured DCs with $200 \mu \mathrm{g} / \mathrm{ml}$ nicotine also significantly suppressed expression of HGMB-1, Tollip and pNFkB-p65 (Supplementary figure 2). The expression of other molecules examined was not significantly affected by CSE or nicotine in immature DCs or LPS-treated DCs (data not shown). 
Culturing polyI:C-matured DCs with 3\% CSE and both concentrations of nicotine suppressed expression of many of the proteins (Figure 2A; columns 3-5 compared to column 1). The quantitative analysis of this RPPA data is shown in figure $2 \mathrm{~B}-\mathrm{E}$ for the 17 proteins whose levels in the moDC lysates were significantly altered by the CSE and/or nicotine treatments during stimulation with polyI:C.

Specifically, figure 2Bi-viii show proteins whose expression is associated with DC maturation and T cell stimulation (pNFkB-p65, c-REL, IRAK4, p-AKT Threonine, nNOS, HMGB1, TNFL6, IRAK-M): these showed lower expression in moDCs treated with CSE and/or nicotine. Figure 2Ci-ii show proteins whose expression is associated with TLRdependent pathways of DC activation (MYD88, p-IRF3): these only showed higher expression with addition of $1 \% \mathrm{CSE}$. Figure 2Di-ii show proteins whose expression is associated with cell survival (BCL-XL, SOD-1): these showed lower expression with addition of both CSE and nicotine. Figure 2Ei-iii show proteins associated with migration (CXCR4, CD74, PIP5K1C): CXCR4 and PIP5KIC show lower expression with the addition of both CSE or nicotine, whereas CD74 shows higher expression with the addition of CSE or nicotine.

\section{Discussion}

This study demonstrates that CSE and nicotine inhibit the expression of proteins required for the activation, survival and migration of moDCs, as well as their ability to activate T cells. In other words, constituents of tobacco smoke suppress the immunogenic potential of DCs.

This provides a molecular basis for the reported inhibition of DC maturation and function by CSE and nicotine [6-19]. The concentrations of CSE $(0.5 \%$ and $3 \%)$ and nicotine $(12 \mu \mathrm{g} / \mathrm{ml}$ and $200 \mu \mathrm{g} / \mathrm{ml}$ ) employed in this study were based on those used in previous studies $[24,27$, $28,30,31,33-35]$. Although the systemic blood concentrations of nicotine in smokers are much lower $(20-60 \mathrm{ng} / \mathrm{ml})[36,37]$, our aim was to produce a reasonable model of the concentrations of cigarette smoke constituents (including nicotine) in the tissues of the respiratory tract directly exposed to these tobacco constituents during smoking. In addition, nicotine is known to concentrate in particular body tissues, including the lung and spleen [36].

The effects were most pronounced on poly I:C-stimulated DCs than on immature or LPS-stimulated moDCs. This may be because, on the one hand, the expression levels of 
signaling molecules in immature DCs are generally lower than in stimulated DCs, and so are less likely to be significantly suppressed by CSE or nicotine; on the other hand, LPS appears to up-regulate expression of the signaling molecules more strongly that does poly I:C, and so may be more resistant to suppression. Furthermore, as discussed below, because poly I:C is a surrogate for the effects of viruses on DCs (whereas LPS is a bacterial product), this is especially relevant in the context of both viruses and smoking being recognized environmental factors in susceptibility to autoimmune diseases.

Several proteins associated with DC maturation and T cell stimulation were downregulated by CSE and/or nicotine in poly I:C stimulated Dot. NF- $\kappa B$ subunits $\mathrm{p} 65$ and c-Rel were down-regulated - these promote T cell activation by DCs [38, 39]; IRAK-4 and AKT were down-regulated and contribute to DC maturation and T cell activation [40, 41]. Neuronal nitric oxide synthase (nNOS) was downregulated by nicotine - this induces synthesis of nitric oxide in human DCs, necessary for their maturation [42]. HMGB1 was downregulated, which DCs secrete to promote activity and expansion of lymphocytes [43]. TNFL6 (FasL/CD95L) is involved in activation-induced cell death, but also has costimulatory properties [44]. IRAK-M inhibits DC activation and pro-inflammatory cytokine production [45]: its down-regulation in nicotine-treated DCs could be a feedback response to down-regulation of DC-stimulatory proteins.

MYD88 and IRF-3 are involved in TLR-dependent DC activation [46, 47]: their expression in polyI:C-stimulated DCs was not affected by nicotine or 3\% CSE; however, both were significantly enhanced by $1 \%$ CSE. This differential effect on human moDCs of low dose and higher dose CSE is consistent with the reported opposite effects of CSE on murine bmDCs dependent on length of exposure, with shorter exposure being stimulatory and longer exposure suppressive [12].

Proteins associated with cell survival were also affected. BCL-XL, an anti-apoptotic factor required for DC survival [48], and SOD1 (superoxide dismutase-1), which promotes cell survival by removing reactive oxygen species [49], were donw-regulated in poly I:Cstimulated moDCs by $3 \%$ CSE or nicotine, potentially leading to reduced DC viability.

Expression of molecules associated with DC migration were affected in polyI:Cstimulated DCs by $3 \%$ CSE, 12 and $200 \mu \mathrm{g} / \mathrm{ml}$ nicotine. CXCR 4 promotes chemotaxis and survival of mature DCs [50] - this was down-regulated by 3\% CSE or nicotine. CD74, the MHC class II-associated invariant chain (Ii), was up-regulated by $3 \%$ CSE and nicotine. However, this may reduce DC migration since CD74 reduces DC motility [51]. PIP5K1C is 
involved in cell migration [52] and its expression was reduced in moDCs by $3 \%$ CSE or nicotine. Thus, CSE and nicotine inhibit the expression of proteins required for the activation, survival and migration of moDCs, and their ability to activate T cells.

Cigarette smoking is a significant environmental risk factor for a variety of autoimmune diseases [53], including multiple sclerosis (MS) [54], systemic lupus erythematosus (SLE) [55] and rheumatoid arthritis [56]. In addition, cigarette smoke (CS) is the main environmental factor associated with chronic obstructive pulmonary disease (COPD), in which autoimmunity also plays a role [57-59]. The association of CS with both autoimmunity and immunosuppression is reminiscent of the well-documented association of autoimmunity with immunodeficiencies, in which it has been hypothesized that persistent infection, due to deficient immunity, can lead to the breakdown of tolerance and thus the generation of autoimmunity, which is of relevance here [60]. In this study, poly I:C mimics the action of the pathogen-associated molecular pattern (PAMP) viral double-stranded RNA. Virus infections are considered to be significant environmental factors in autoimmune diseases [61] and COPD [62], and the suppression of DC maturation by CS and nicotine could help to facilitate this.

\section{Conflicts of interest statement}

None to declare.

\section{Acknowledgments}

NA was supported by King Abdulaziz University and Ministry of Higher Education, Saudi Arabia. ON is affiliated to Medical Microbiology and Immunology Department, Mansoura University, Egypt. This work was supported by The Jones 1986 Charitable Trust.

\section{References}

[1] A. Broggi, I. Zanoni, F. Granucci, Migratory conventional dendritic cells in the induction of peripheral T cell tolerance, Journal of leukocyte biology, 94 (2013) 903-911.

[2] D. Ganguly, S. Haak, V. Sisirak, B. Reizis, The role of dendritic cells in autoimmunity, Nat Rev Immunol, 13 (2013) 566-577.

[3] F. Benvenuti, The Dendritic Cell Synapse: A Life Dedicated to T Cell Activation, Front Immunol, 7 (2016) 70.

[4] O.P. Joffre, E. Segura, A. Savina, S. Amigorena, Cross-presentation by dendritic cells, Nat Rev Immunol, 12 (2012) 557-569. 
[5] V.K. Raker, M.P. Domogalla, K. Steinbrink, Tolerogenic Dendritic Cells for Regulatory T Cell Induction in Man, Front Immunol, 6 (2015) 569.

[6] M.R. Stampfli, G.P. Anderson, How cigarette smoke skews immune responses to promote infection, lung disease and cancer, Nat Rev Immunol, 9 (2009) 377-384.

[7] C.S. Robbins, D.E. Dawe, S.I. Goncharova, M.A. Pouladi, A.G. Drannik, F.K. Swirski, G. Cox, M.R. Stampfli, Cigarette smoke decreases pulmonary dendritic cells and impacts antiviral immune responsiveness, American journal of respiratory cell and molecular biology, 30 (2004) 202-211.

[8] C.S. Robbins, F. Franco, M. Mouded, M. Cernadas, S.D. Shapiro, Cigarette smoke exposure impairs dendritic cell maturation and T cell proliferation in thoracic lymph nodes of mice, J Immunol, 180 (2008) 6623-6628.

[9] S.X. Liao, T. Ding, X.M. Rao, D.S. Sun, P.P. Sun, Y.J. Wang, D.D. Fu, X.L. Liu, Y. Ou-Yang, Cigarette smoke affects dendritic cell maturation in the small airways of patients with chronic obstructive pulmonary disease, Molecular medicine reports, 11 (2015) 219-225.

[10] E. Arellano-Orden, C. Calero-Acuna, N. Moreno-Mata, L. Gomez-Izquierdo, V. SanchezLopez, C. Lopez-Ramirez, D. Tobar, J.L. Lopez-Villalobos, C. Gutierrez, A. Blanco-Orozco, J.L. Lopez-Campos, Cigarette Smoke Decreases the Maturation of Lung Myeloid Dendritic Cells, PLoS One, 11 (2016) e0152737.

[11] E. Mortaz, A.D. Kraneveld, J.J. Smit, M. Kool, B.N. Lambrecht, S.L. Kunkel, N.W. Lukacs, F.P. Nijkamp, G. Folkerts, Effect of cigarette smoke extract on dendritic cells and their impact on T-cell proliferation, PLoS One, 4 (2009) e4946.

[12] M.E. Givi, G. Folkerts, G.T. Wagenaar, F.A. Redegeld, E. Mortaz, Cigarette smoke differentially modulates dendritic cell maturation and function in time, Respir Res, 16 (2015) 131.

[13] R. Vassallo, K. Tamada, J.S. Lau, P.R. Kroening, L. Chen, Cigarette smoke extract suppresses human dendritic cell function leading to preferential induction of Th-2 priming, J Immunol, 175 (2005) 2684-2691.

[14] P.R. Kroening, T.W. Barnes, L. Pease, A. Limper, H. Kita, R. Vassallo, Cigarette smokeinduced oxidative stress suppresses generation of dendritic cell IL-12 and IL-23 through ERKdependent pathways, J Immunol, 181 (2008) 1536-1547.

[15] O. Le Rouzic, B. Kone, J. Kluza, P. Marchetti, F. Hennegrave, C. Olivier, G. Kervoaze, E. Vilain, C. Mordacq, N. Just, T. Perez, N. Bautin, M. Pichavant, P. Gosset, Cigarette smoke alters the ability of human dendritic cells to promote anti-Streptococcus pneumoniae Th17 response, Respir Res, 17 (2016) 94.

[16] M. Nouri-Shirazi, E. Guinet, Evidence for the immunosuppressive role of nicotine on human dendritic cell functions, Immunology, 109 (2003) 365-373.

[17] E. Guinet, K. Yoshida, M. Nouri-Shirazi, Nicotinic environment affects the differentiation and functional maturation of monocytes derived dendritic cells (DCs), Immunology letters, 95 (2004) 45-55.

[18] M. Nouri-Shirazi, E. Guinet, A possible mechanism linking cigarette smoke to higher incidence of respiratory infection and asthma, Immunology letters, 103 (2006) 167-176. [19] M. Nouri-Shirazi, R. Tinajero, E. Guinet, Nicotine alters the biological activities of developing mouse bone marrow-derived dendritic cells (DCs), Immunology letters, 109 (2007) 155-164.

[20] R. Zdanowski, M. Krzyzowska, D. Ujazdowska, A. Lewicka, S. Lewicki, Role of alpha7 nicotinic receptor in the immune system and intracellular signaling pathways, Cent Eur J Immunol, 40 (2015) 373-379. 
[21] O.H. Negm, H.A. Mannsperger, E.M. McDermott, E. Drewe, R.J. Powell, I. Todd, L.C. Fairclough, P.J. Tighe, A pro-inflammatory signalome is constitutively activated by C33Y mutant TNF receptor 1 in TNF receptor-associated periodic syndrome (TRAPS), Eur J Immunol, 44 (2014) 2096-2110.

[22] R.A. Urbanowicz, J.R. Lamb, I. Todd, J.M. Corne, L.C. Fairclough, Altered effector function of peripheral cytotoxic cells in COPD, Respir Res, 10 (2009) 53.

[23] S. Selvarajah, O.H. Negm, M.R. Hamed, C. Tubby, I. Todd, P.J. Tighe, T. Harrison, L.C. Fairclough, Development and validation of protein microarray technology for simultaneous inflammatory mediator detection in human sera, Mediators of inflammation, 2014 (2014) 820304.

[24] K. Aoshiba, J. Tamaoki, A. Nagai, Acute cigarette smoke exposure induces apoptosis of alveolar macrophages, American journal of physiology. Lung cellular and molecular physiology, 281 (2001) L1392-1401.

[25] D. Bernhard, C.W. Huck, T. Jakschitz, G. Pfister, B. Henderson, G.K. Bonn, G. Wick, Development and evaluation of an in vitro model for the analysis of cigarette smoke effects on cultured cells and tissues, Journal of pharmacological and toxicological methods, 50 (2004) 45-51.

[26] X. Liu, H. Conner, T. Kobayashi, H. Kim, F. Wen, S. Abe, Q. Fang, X. Wang, M. Hashimoto, P. Bitterman, S.I. Rennard, Cigarette smoke extract induces DNA damage but not apoptosis in human bronchial epithelial cells, American journal of respiratory cell and molecular biology, 33 (2005) 121-129.

[27] M.F. Mian, N.M. Lauzon, M.R. Stampfli, K.L. Mossman, A.A. Ashkar, Impairment of human NK cell cytotoxic activity and cytokine release by cigarette smoke, Journal of leukocyte biology, 83 (2008) 774-784.

[28] M.F. Mian, E.A. Pek, K.L. Mossman, M.R. Stampfli, A.A. Ashkar, Exposure to cigarette smoke suppresses IL-15 generation and its regulatory NK cell functions in poly I:Caugmented human PBMCs, Molecular immunology, 46 (2009) 3108-3116.

[29] K.A. Stringer, M. Tobias, H.C. O'Neill, C.C. Franklin, Cigarette smoke extract-induced suppression of caspase-3-like activity impairs human neutrophil phagocytosis, American journal of physiology. Lung cellular and molecular physiology, 292 (2007) L1572-1579. [30] Y. Su, W. Cao, Z. Han, E.R. Block, Cigarette smoke extract inhibits angiogenesis of pulmonary artery endothelial cells: the role of calpain, American journal of physiology. Lung cellular and molecular physiology, 287 (2004) L794-800.

[31] C. Wongtrakool, K. Grooms, K.M. Bijli, K. Crothers, A.M. Fitzpatrick, C.M. Hart, Nicotine stimulates nerve growth factor in lung fibroblasts through an NFkappaB-dependent mechanism, PLoS One, 9 (2014) e109602.

[32] M.J. Jarvis, R. Boreham, P. Primatesta, C. Feyerabend, A. Bryant, Nicotine yield from machine-smoked cigarettes and nicotine intakes in smokers: evidence from a representative population survey, Journal of the National Cancer Institute, 93 (2001) 134-138.

[33] S.F. Cheng, X.S. Qin, Z.L. Han, X.F. Sun, Y.N. Feng, F. Yang, W. Ge, L. Li, Y. Zhao, M. De Felici, S.H. Zou, Y. Zhou, W. Shen, Nicotine exposure impairs germ cell development in human fetal ovaries cultured in vitro, Aging, (2018).

[34] S.D. Daffner, S. Waugh, T.L. Norman, N. Mukherjee, J.C. France, Nicotine Increases Osteoblast Activity of Induced Bone Marrow Stromal Cells in a Dose-Dependent Manner: An in vitro Cell Culture Experiment, Global Spine J, 2 (2012) 153-158.

[35] F. Tinti, M. Soory, Mechanisms for redox actions of nicotine and glutathione in cell culture, relevant to periodontitis, Scientific reports, 2 (2012) 566. 
[36] N.L. Benowitz, J. Hukkanen, P. Jacob, 3rd, Nicotine chemistry, metabolism, kinetics and biomarkers, Handb Exp Pharmacol, (2009) 29-60.

[37] M.A. Russell, M. Jarvis, R. Iyer, C. Feyerabend, Relation of nicotine yield of cigarettes to blood nicotine concentrations in smokers, Br Med J, 280 (1980) 972-976.

[38] S.W. Tas, E.C. de Jong, N. Hajji, M.J. May, S. Ghosh, M.J. Vervoordeldonk, P.P. Tak, Selective inhibition of NF-kappaB in dendritic cells by the NEMO-binding domain peptide blocks maturation and prevents T cell proliferation and polarization, Eur J Immunol, 35 (2005) 1164-1174.

[39] J. Wang, X. Wang, S. Hussain, Y. Zheng, S. Sanjabi, F. Ouaaz, A.A. Beg, Distinct roles of different NF-kappa B subunits in regulating inflammatory and T cell stimulatory gene expression in dendritic cells, J Immunol, 178 (2007) 6777-6788.

[40] N. Suzuki, S. Suzuki, U. Eriksson, H. Hara, C. Mirtosis, N.J. Chen, T. Wada, D. Bouchard, I. Hwang, K. Takeda, T. Fujita, S. Der, J.M. Penninger, S. Akira, T. Saito, W.C. Yeh, IL-1Rassociated kinase 4 is required for lipopolysaccharide-induced activation of APC, J Immunol, 171 (2003) 6065-6071.

[41] J.H. Kim, T.H. Kang, K.H. Noh, S.H. Kim, Y.H. Lee, K.W. Kim, H.C. Bae, Y.H. Ahn, E.Y. Choi, J.S. Kim, K.M. Lee, T.W. Kim, Enhancement of DC vaccine potency by activating the PI3K/AKT pathway with a small interfering RNA targeting PTEN, Immunology letters, 134 (2010) 47-54. [42] H.S. Adler, A. Simon, E. Graulich, A. Habermeier, N. Bacher, A. Friebe, E.I. Closs, K.

Steinbrink, Neuronal nitric oxide synthase modulates maturation of human dendritic cells, J Immunol, 184 (2010) 6025-6034.

[43] G. Li, X. Liang, M.T. Lotze, HMGB1: The Central Cytokine for All Lymphoid Cells, Front Immunol, 4 (2013) 68.

[44] O. Janssen, J. Qian, A. Linkermann, D. Kabelitz, CD95 ligand--death factor and costimulatory molecule?, Cell death and differentiation, 10 (2003) 1215-1225.

[45] J. Shiu, S.J. Czinn, K.S. Kobayashi, Y. Sun, T.G. Blanchard, IRAK-M expression limits dendritic cell activation and proinflammatory cytokine production in response to Helicobacter pylori, PLoS One, 8 (2013) e66914.

[46] G.C. Macedo, D.M. Magnani, N.B. Carvalho, O. Bruna-Romero, R.T. Gazzinelli, S.C. Oliveira, Central role of MyD88-dependent dendritic cell maturation and proinflammatory cytokine production to control Brucella abortus infection, J Immunol, 180 (2008) 1080-1087. [47] R. Saenz, D. Futalan, L. Leutenez, F. Eekhout, J.F. Fecteau, S. Sundelius, S. Sundqvist, M. Larsson, T. Hayashi, B. Minev, D. Carson, S. Esener, B. Messmer, D. Messmer, TLR4dependent activation of dendritic cells by an HMGB1-derived peptide adjuvant, J Transl Med, 12 (2014) 211.

[48] H. Hon, E.B. Rucker, 3rd, L. Hennighausen, J. Jacob, bcl-xL is critical for dendritic cell survival in vivo, J Immunol, 173 (2004) 4425-4432.

[49] H.L. Liang, J. Arsenault, J. Mortensen, F. Park, C.P. Johnson, V. Nilakantan, Partial attenuation of cytotoxicity and apoptosis by SOD1 in ischemic renal epithelial cells, Apoptosis, 14 (2009) 1176-1189.

[50] C. Delgado-Martin, C. Escribano, J.L. Pablos, L. Riol-Blanco, J.L. Rodriguez-Fernandez, Chemokine CXCL12 uses CXCR4 and a signaling core formed by bifunctional Akt, extracellular signal-regulated kinase (ERK)1/2, and mammalian target of rapamycin complex 1 (mTORC1) proteins to control chemotaxis and survival simultaneously in mature dendritic cells, The Journal of biological chemistry, 286 (2011) 37222-37236.

[51] G. Faure-Andre, P. Vargas, M.I. Yuseff, M. Heuze, J. Diaz, D. Lankar, V. Steri, J. Manry, S. Hugues, F. Vascotto, J. Boulanger, G. Raposo, M.R. Bono, M. Rosemblatt, M. Piel, A.M. 
Lennon-Dumenil, Regulation of dendritic cell migration by CD74, the MHC class II-associated invariant chain, Science, 322 (2008) 1705-1710.

[52] W. Xu, P. Wang, B. Petri, Y. Zhang, W. Tang, L. Sun, H. Kress, T. Mann, Y. Shi, P. Kubes, D. Wu, Integrin-induced PIP5K1C kinase polarization regulates neutrophil polarization, directionality, and in vivo infiltration, Immunity, 33 (2010) 340-350.

[53] C. Perricone, M. Versini, D. Ben-Ami, S. Gertel, A. Watad, M.J. Segel, F. Ceccarelli, F. Conti, L. Cantarini, D.P. Bogdanos, A. Antonelli, H. Amital, G. Valesini, Y. Shoenfeld, Smoke and autoimmunity: The fire behind the disease, Autoimmunity reviews, 15 (2016) 354-374. [54] L. Belbasis, V. Bellou, E. Evangelou, J.P. Ioannidis, I. Tzoulaki, Environmental risk factors and multiple sclerosis: an umbrella review of systematic reviews and meta-analyses, The Lancet. Neurology, 14 (2015) 263-273.

[55] S.U. Takvorian, J.F. Merola, K.H. Costenbader, Cigarette smoking, alcohol consumption and risk of systemic lupus erythematosus, Lupus, 23 (2014) 537-544.

[56] H. Kallberg, B. Ding, L. Padyukov, C. Bengtsson, J. Ronnelid, L. Klareskog, L. Alfredsson, E.S. Group, Smoking is a major preventable risk factor for rheumatoid arthritis: estimations of risks after various exposures to cigarette smoke, Ann Rheum Dis, 70 (2011) 508-511. [57] R. Faner, T. Cruz, A. Agusti, Immune response in chronic obstructive pulmonary disease, Expert Rev Clin Immunol, 9 (2013) 821-833.

[58] G. Caramori, P. Casolari, A. Barczyk, A.L. Durham, A. Di Stefano, I. Adcock, COPD immunopathology, Semin Immunopathol, 38 (2016) 497-515.

[59] R. Shindi, A. Almehairi, O.H. Negm, N. Kalsheker, N.S. Gale, D.J. Shale, T.W. Harrison, C.E. Bolton, M. John, I. Todd, P.J. Tighe, L.C. Fairclough, Autoantibodies of IgM and IgG classes show differences in recognition of multiple autoantigens in chronic obstructive pulmonary disease, Clinical immunology, (2017).

[60] G.J. Arason, G.H. Jorgensen, B.R. Ludviksson, Primary immunodeficiency and autoimmunity: lessons from human diseases, Scandinavian journal of immunology, 71 (2010) 317-328.

[61] D.R. Getts, E.M. Chastain, R.L. Terry, S.D. Miller, Virus infection, antiviral immunity, and autoimmunity, Immunol Rev, 255 (2013) 197-209.

[62] H. Frickmann, S. Jungblut, T.O. Hirche, U. Gross, M. Kuhns, A.E. Zautner, The influence of virus infections on the course of COPD, Eur J Microbiol Immunol (Bp), 2 (2012) 176-185. 


\section{Figure legends}

Figure 1. i) Phenotypic analysis of moDCs by flow cytometry: the expression of the surface molecules was detected using a Beckman-Coulter FC500 flow cytometer. Anti-CD80-FITC, anti-CD86-PE, anti-CD83-PC5 and anti-DC-SIGN-PC7 conjugated antibodies were used for the extracellular staining of the cells and the data were analysed with Weasel v3.0.2. software. Comparison between the mean fluorescence intensity (MFI) values of immature and LPS- or poly I:C-treated (mature) moDCs presented as Box \& Whisker plots showing the median, interquartile range and minimum and maximum values. Wilcoxon matched pairs test was used to assess statistical differences in marker expression between immature and mature DCs: $* \mathrm{p} \leq 0.05, * * \mathrm{p} \leq 0.01 ; \mathrm{n}=8$ for LPS-stimulated DCs and $\mathrm{n}=6$ for poly I:C-stimulated DCs. ii) Comparison between cytokine secretion by immature and LPS- or polyI:C-treated (mature) moDCs $(n=6)$. The concentrations of IL-12, IL-10, IL-8, IL-6 and TNF- $\alpha$ secreted by immature, LPS- or polyI:C-matured DCs were determined using antibody microarray. Levels of IL-12 and IL-10 produced by immature DCs were undetectable. Wilcoxon matched pairs test was used to assess differences in cytokine production between immature and mature DCs: in all cases $\mathrm{p}=0.03$, except for stimulation of IL- 8 production by polyI:C ( $p=0.06)$. iii) Heat map of RPPA results for levels of 39 signaling molecules and other proteins in whole cell lysates of immature and mature human moDCs. Each row shows expression of an individual protein in the lysates (indicated to the right). Bright red indicates high protein expression; bright green indicates low protein expression. Each individual column represents the levels of the proteins in the lysates of moDCs generated from PBMCderived monocytes of different healthy donors (R1-R8). The left-hand set of columns shows the results for immature DCs; the middle columns show the results for LPS-matured DCs; the right-hand columns show the results for polyI:C-matured DCs.

Figure 2. A) RPPA for polyI:C-matured human moDCs, with or without CSE or nicotine treatment. Each row shows expression of an individual protein in the lysates (indicated to the right). Bright red indicates high protein expression; bright green indicates low protein expression. Each individual column represents the levels of the proteins in the lysates of moDCs generated from PBMC-derived monocytes of different healthy donors (R1R8). Each set of columns shows the results for DCs that were either untreated (1), or treated 
with $1 \% \operatorname{CSE}(2), 3 \% \mathrm{CSE}(3), 12 \mu \mathrm{g} / \mathrm{ml}$ nicotine (4) or $200 \mu \mathrm{g} / \mathrm{ml}$ nicotine (5). B-E) RPPA for poly I:C-treated human moDCs, with or without CSE or nicotine treatment. The analysis of 15 molecules is represented in scatter plots showing the means of each group. Each dot represents the mean of three replicates of the same normal individual. $\mathrm{n}=6$ for controls and for $3 \%$ CSE-treated cells, $\mathrm{n}=7$ for $1 \%$ CSE-treated cells, and $\mathrm{n}=8$ for $12 \mu \mathrm{g} / \mathrm{ml}$ and $200 \mu \mathrm{g} / \mathrm{ml}$ nicotine-treated cells. Figure 2Bi-viii show proteins whose expression is associated with DC maturation and $\mathrm{T}$ cell stimulation; figure $2 \mathrm{Ci}$-ii show proteins whose expression is associated with TLR-dependent pathways of DC activation; figure 2Di-ii show proteins whose expression is associated with cell survival; figure 2Ei-iii show proteins associated with migration. 
i) a) $C D 80$

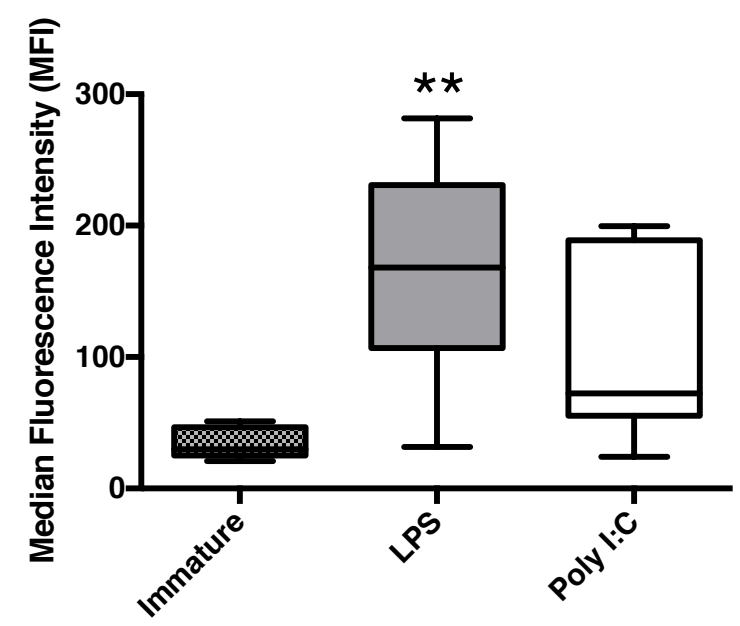

c) CD83

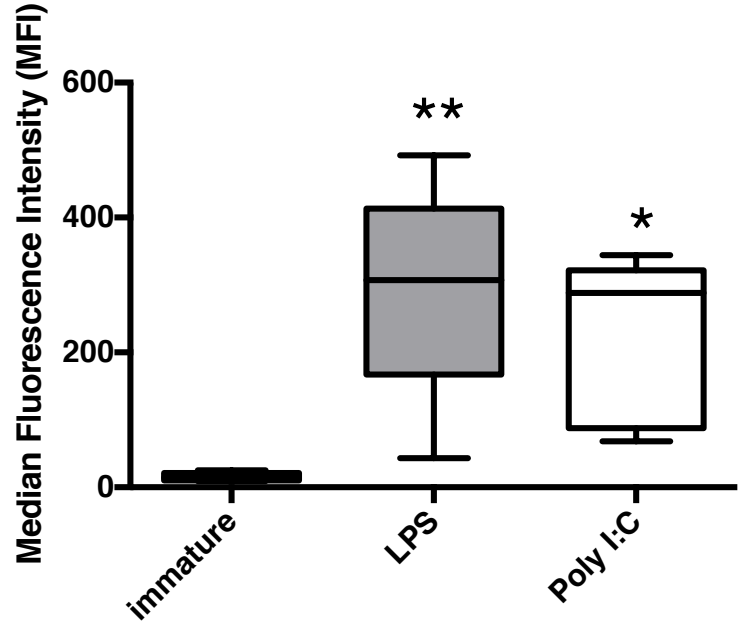

ii)

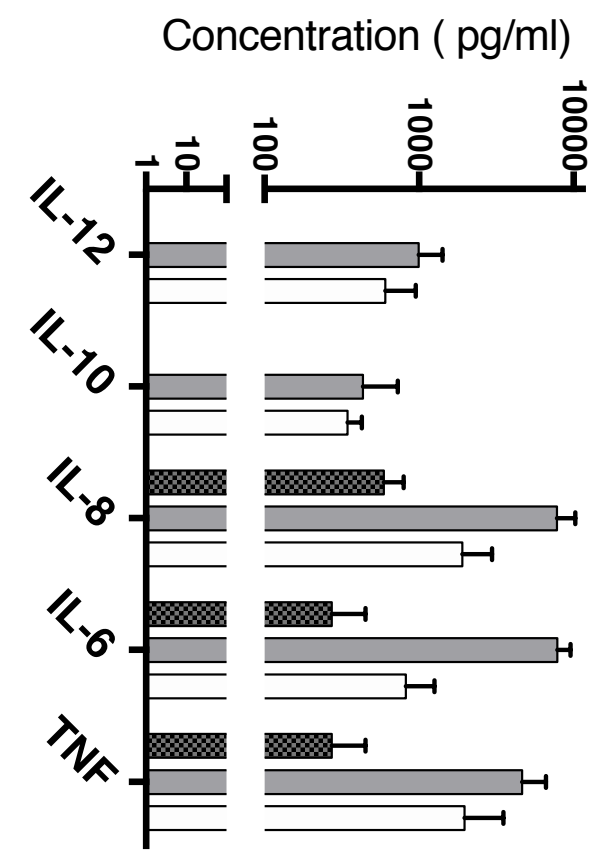

종 Immature

$\square$ LPS

$\square$ Poly I:C b) CD86

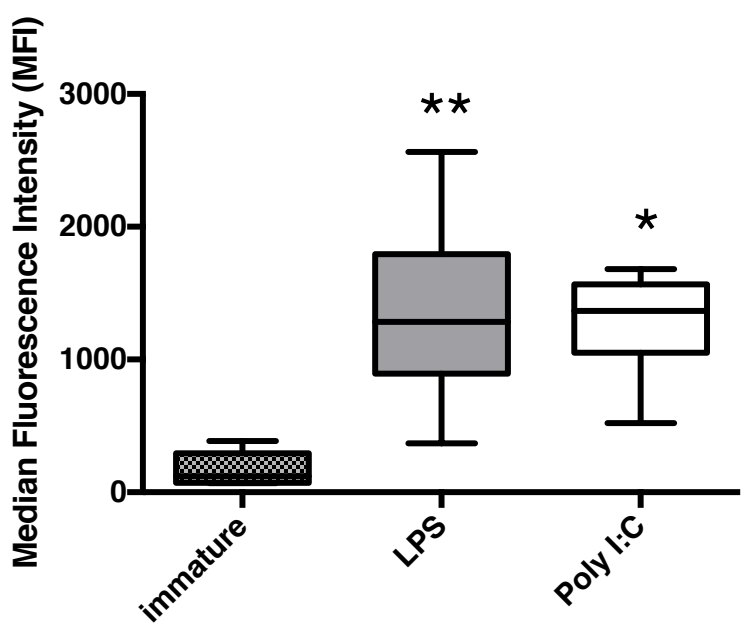

d) DC-SIGN

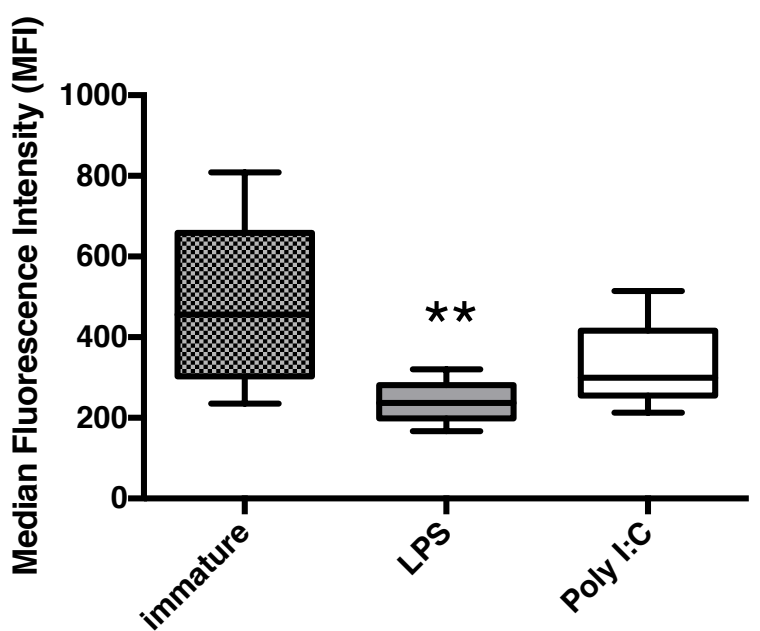

iii)

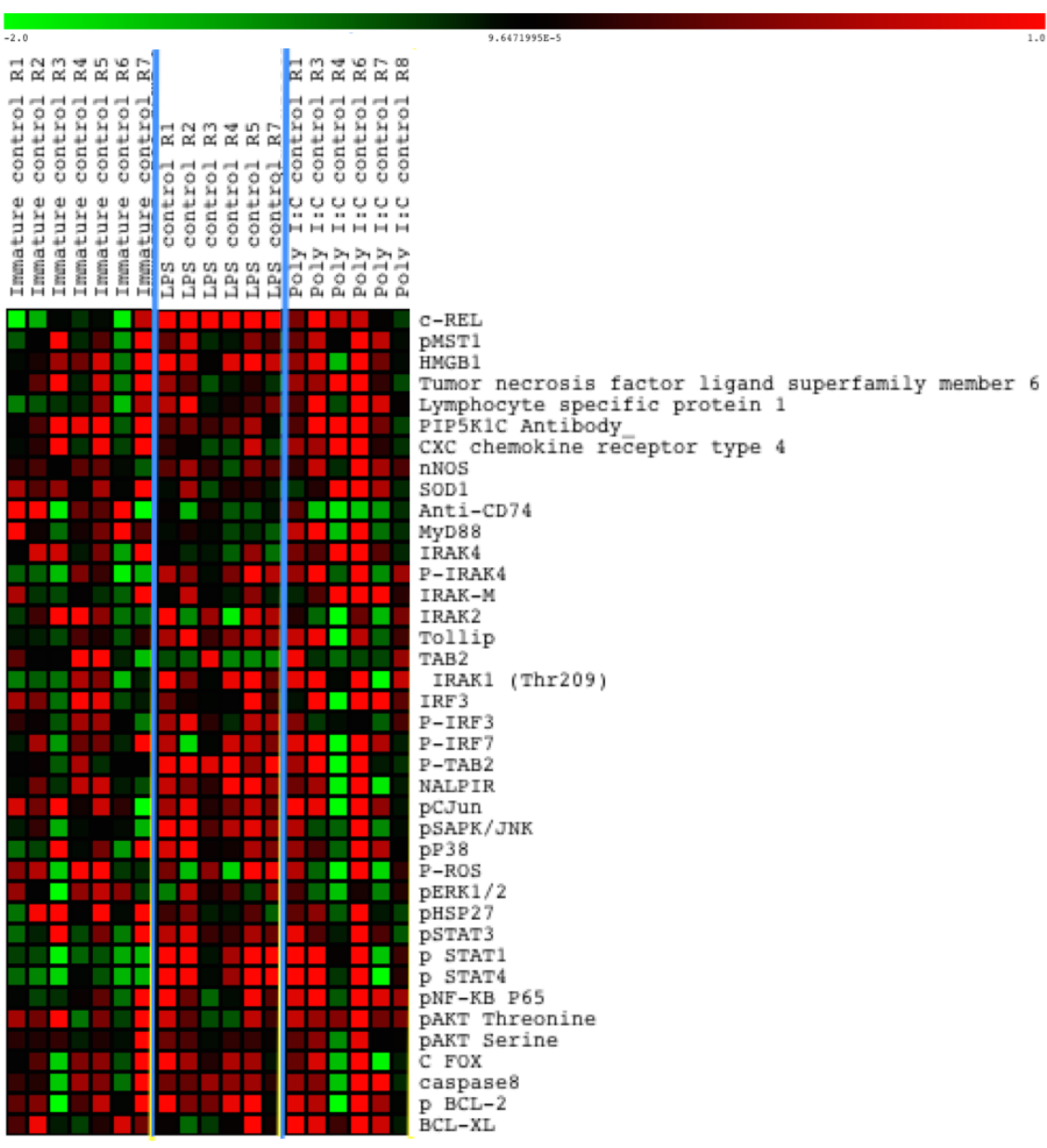



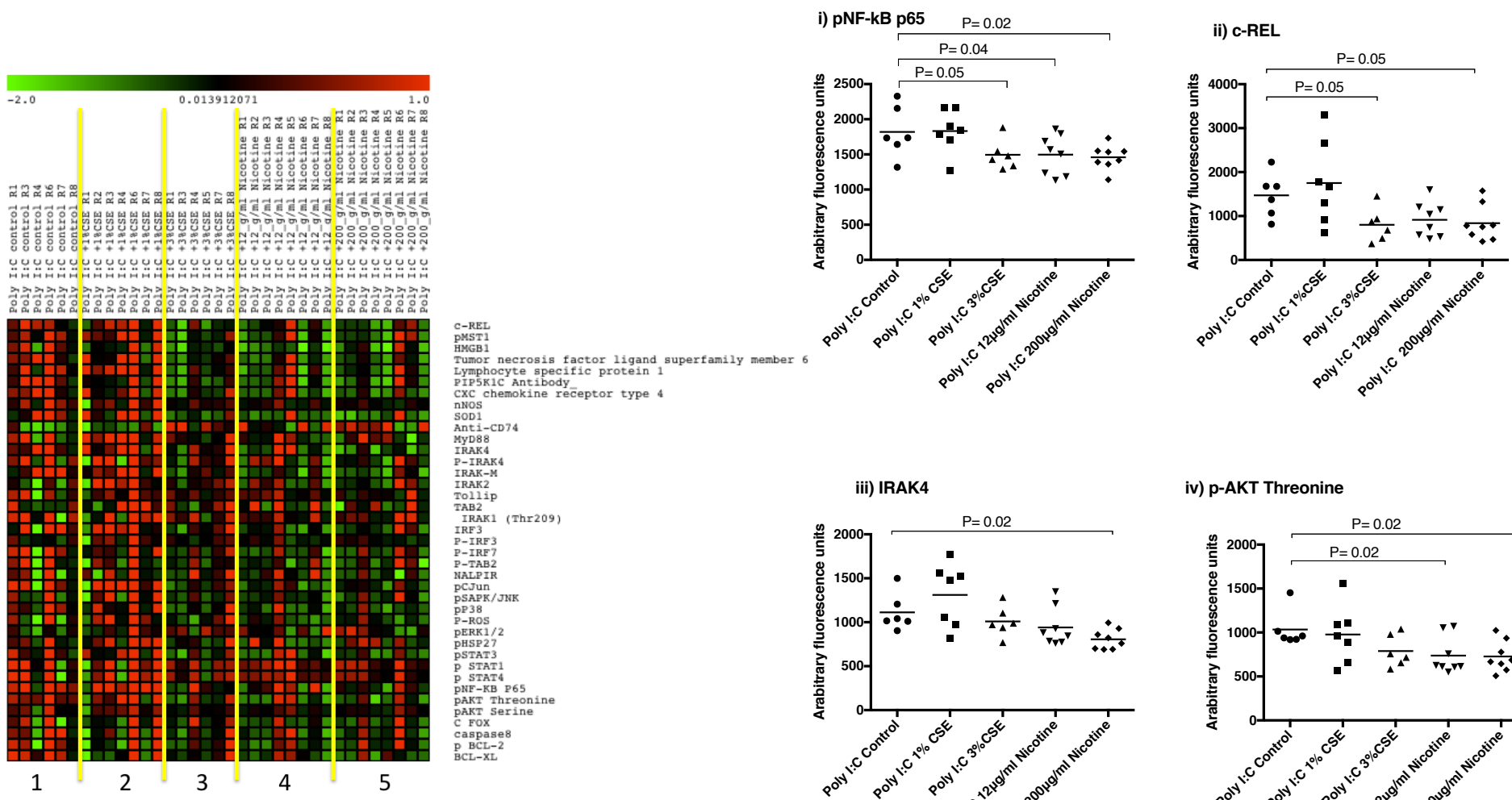

iii) IRAK4

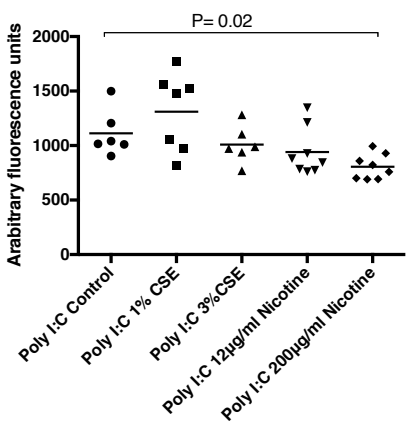

vii) TNFL6
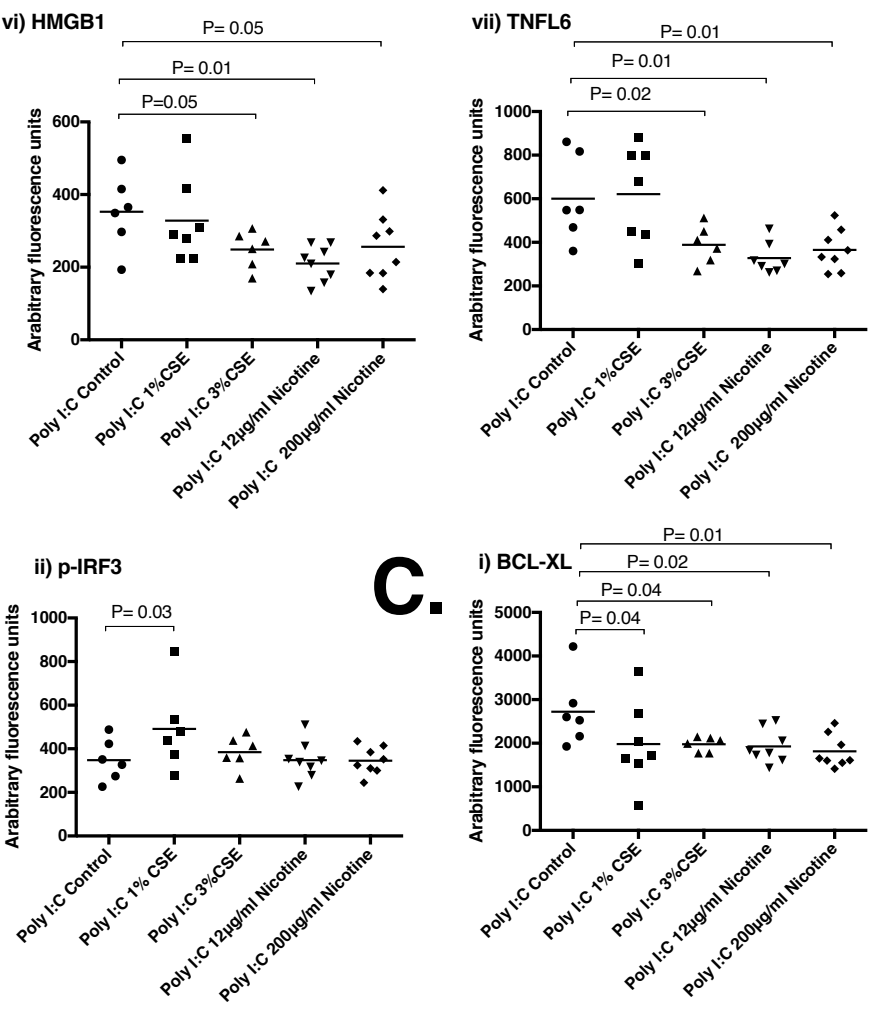

iii) PIP5K1C

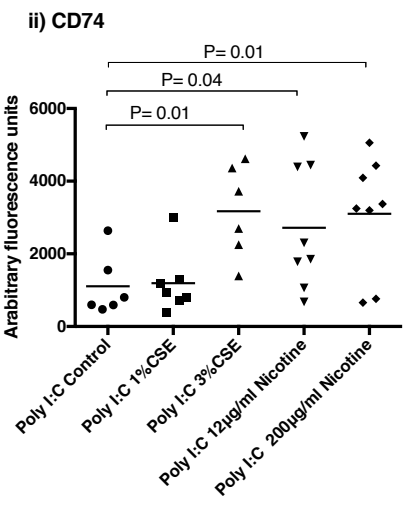

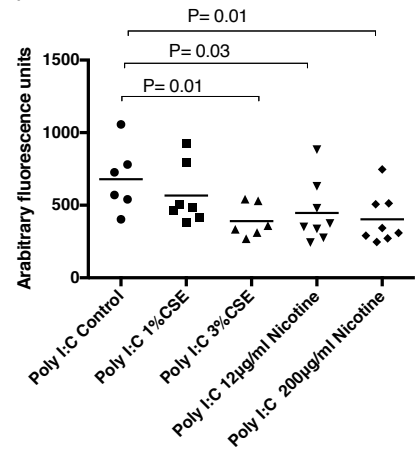

iv) p-AKT Threonine

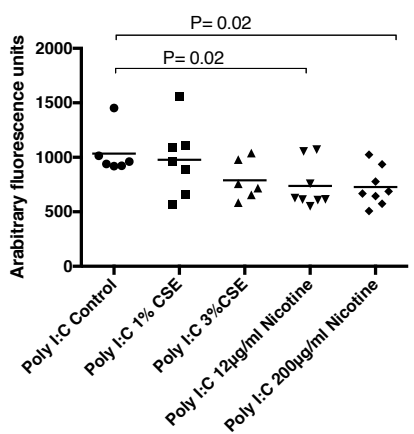

viii) IRAK-M
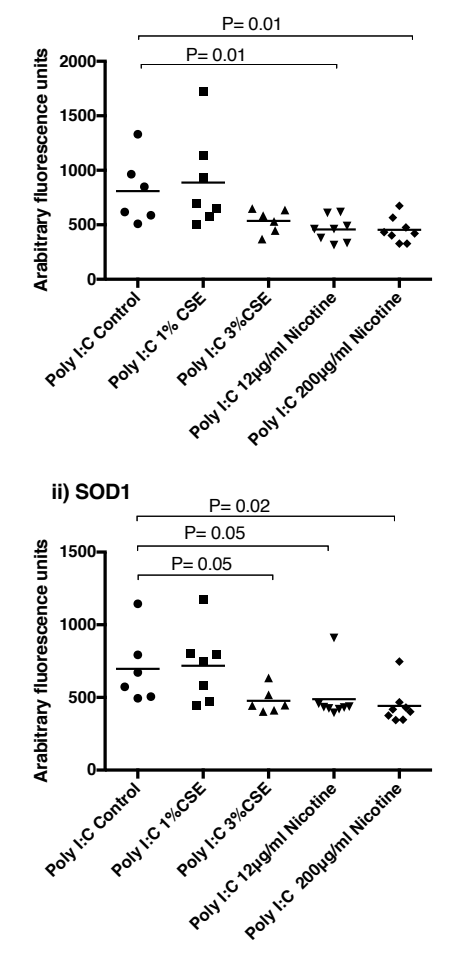

D.

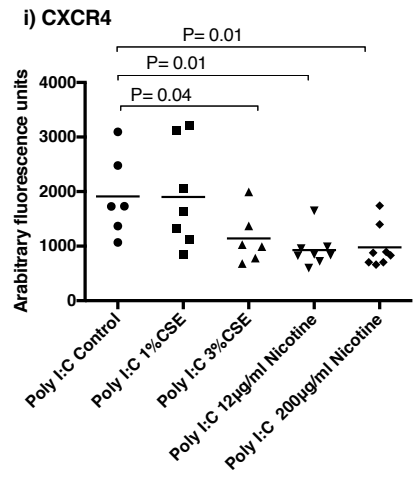

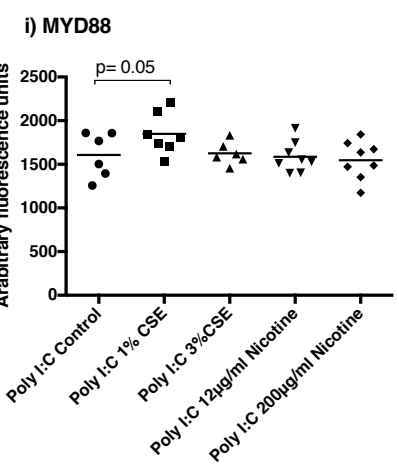


Supplementary Material - Tobacco smoke and nicotine suppress expression of activating signaling molecules in human dendritic cells

Nuha Alkhattabi, Ian Todd, Ola Negm, Patrick J Tighe, Lucy C Fairclough

School of Life Sciences, University of Nottingham, Nottingham, UK

Supplementary table 1. Primary antibodies used for the detection of cell surface differentiation markers by flow cytometry.

\begin{tabular}{|c|c|c|c|c|c|}
\hline $\begin{array}{c}\text { Antibody } \\
\text { specificity }\end{array}$ & Clone & Species & Isotype & Fluorescent label & Source \\
\hline $\mathrm{CD} 80$ & $\mathrm{IM} 1853 \mathrm{U}$ & Mouse & $\operatorname{IgG1}$ & $\begin{array}{c}\text { Fluorescein- } \\
\text { isothiocyanate } \\
\text { (FITC) }\end{array}$ & Beckman-Coulter \\
\hline $\mathrm{CD} 86$ & $\mathrm{IM} 2729 \mathrm{U}$ & Mouse & $\operatorname{IgG} 2 \mathrm{~b}$ & $\begin{array}{c}\text { Phycoerythrin } \\
\text { (PE) }\end{array}$ & Beckman-Coulter \\
\hline $\mathrm{CD} 83$ & $\mathrm{IM} 3240 \mathrm{U}$ & Mouse & $\operatorname{IgG} 2 \mathrm{~b}$ & $\begin{array}{c}\text { Phycoerythrin- } \\
\text { cyanin5 } \\
\text { (PE-Cy5) }\end{array}$ & Beckman-Coulter \\
\hline $\begin{array}{c}\mathrm{CD} 209 \\
(\mathrm{DC}-\mathrm{SIGN})\end{array}$ & $25-2099-42$ & Rat & $\mathrm{IgG2a}$ & $\begin{array}{c}\text { Phycoerythrin- } \\
\text { cyanin } 7 \\
\text { (PE-Cy7) }\end{array}$ & eBioscience \\
\hline
\end{tabular}

Staining for flow cytometric analysis was performed as follows: samples were placed in PBA buffer (phosphate-buffered saline, 20\% sodium azide, 30\% bovine serum albumen, Sigma-Aldrich) and centrifuged at $300 \mathrm{~g}$ for $5 \mathrm{~min}$. The supernatants were discarded and the pellets resuspended in $5 \mu 1$ of the appropriate monoclonal antibodies indicated in the table above; corresponding isotype control antibodies were also employed. Incubation took place in the dark at room temperature for $30 \mathrm{~min}$ and then $1 \mathrm{ml}$ PBA was added followed by centrifugation at $300 \mathrm{~g}$ for $5 \mathrm{~min}$. Finally, the cells were fixed using $400 \mu \mathrm{l}$ of $0.5 \%$ formaldehyde and stored at $4^{\circ} \mathrm{C}$ prior to flow cytometry. 
Supplementary table 2. Primary antibodies used in RPPA to detect proteins of interest in moDC lysates. All sourced from Cell Signaling Technologies, Schuttersveld 2, 2316 ZA Leiden, The Netherlands. Catalogue number (in brackets).

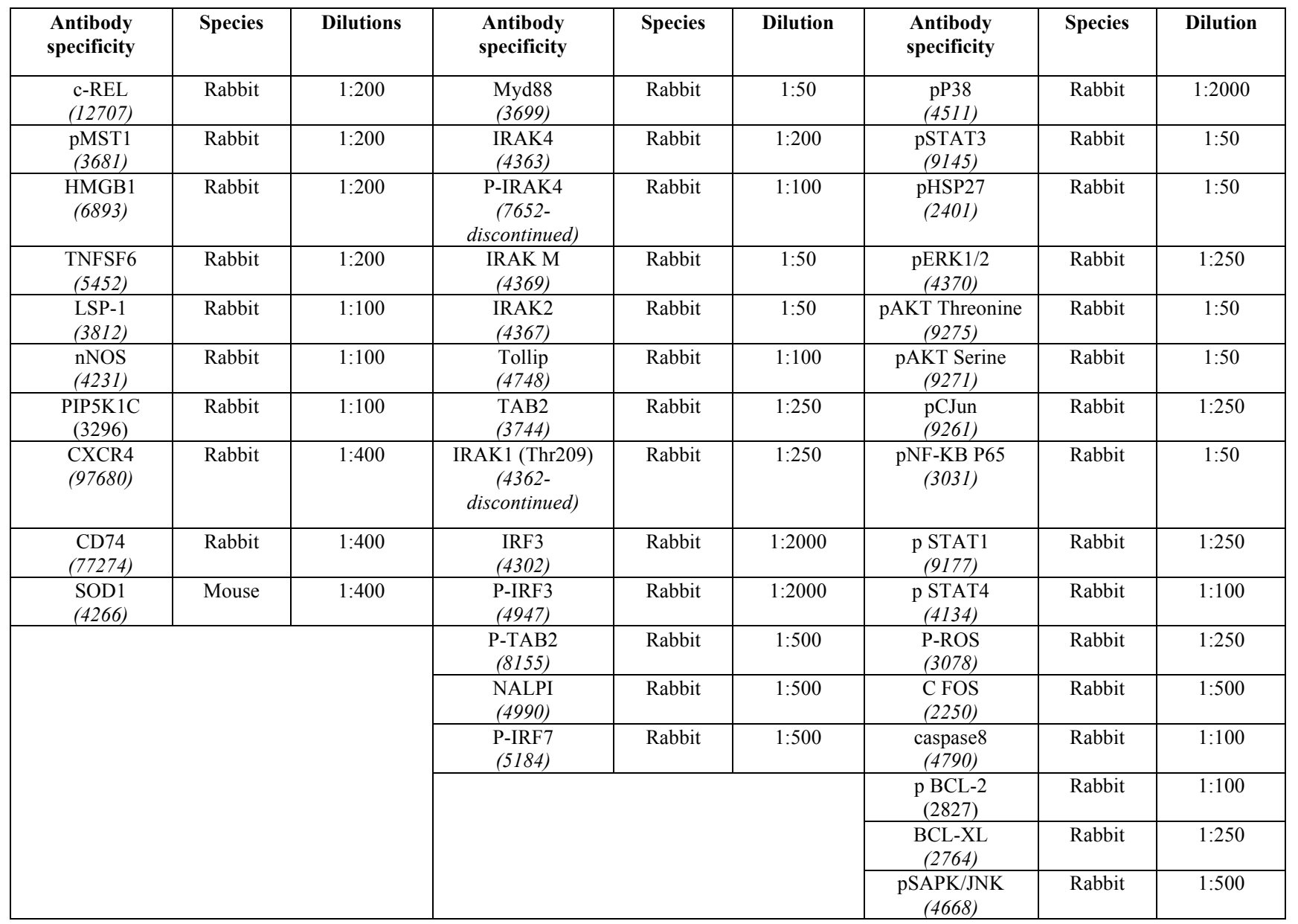

Cell lysates were solubilised in $4 \mathrm{x}$ SDS sample buffer at a 1:3 ratio and heated for $5 \mathrm{~min}$ at $95^{\circ} \mathrm{C}$. Samples were loaded into a 384-well plates (Genetix). Samples were robotically spotted in duplicates as 16 separate arrays onto ONcyte Avid nitrocellulose-coated glass slides (GraceBiolab) using a microarrayer (MicroGrid II). Slides were sealed in a 16-well Proplate incubation gasket (GraceBiolab) to isolate each replicated array and incubated overnight in blocking solution (0.2\% I-block (Tropix), $0.1 \%$ Tween-20 in PBS) at $4{ }^{\circ} \mathrm{C}$ with shaking. After washing, independent arrays on the slides were incubated with primary antibodies diluted in antibody diluent with background reducing agent (Agilent). The antigenic specificity of all primary antibodies was verified by western blotting. Rabbit anti- $\beta$-actin antibody or mouse anti- $\beta$-actin (Sigma Aldrich), diluted 1:1000 in the same diluent, was used to monitor the abundance of housekeeping proteins to control for differences in protein loading. Slides were incubated overnight at $4{ }^{\circ} \mathrm{C}$ with shaking. Following washing, slides were incubated with diluted (1:5000 in washing buffer) secondary antibodies conjugated to infrared dyes, IRDYE-800CW goat anti-rabbit and IRDye-700CW goat anti-mouse (Li-Cor BiotechnologyUK Ltd) for 30min at room temperature in the dark with shaking. Then, slides were washed and dried by centrifugation at $500 \mathrm{~g}$ for $5 \mathrm{~min}$ and scanned with a Li-Cor Odyssey SA scanner at $21 \mu \mathrm{m}$ resolution at 800 $\mathrm{nm}$ (green) and $700 \mathrm{~nm}$ (red). The resultant TIFF images were processed with Axon Genepix Pro-6 Microarray Image Analysis software (Molecular Devices) to obtain fluorescence data for each feature and to generate standard gpr files. Protein signals were finally determined after background subtraction and normalization to the internal housekeeping targets using the RPPanalyzer, a module within the R statistical language on the CRAN (http://cran.r-project.org/). 
A.
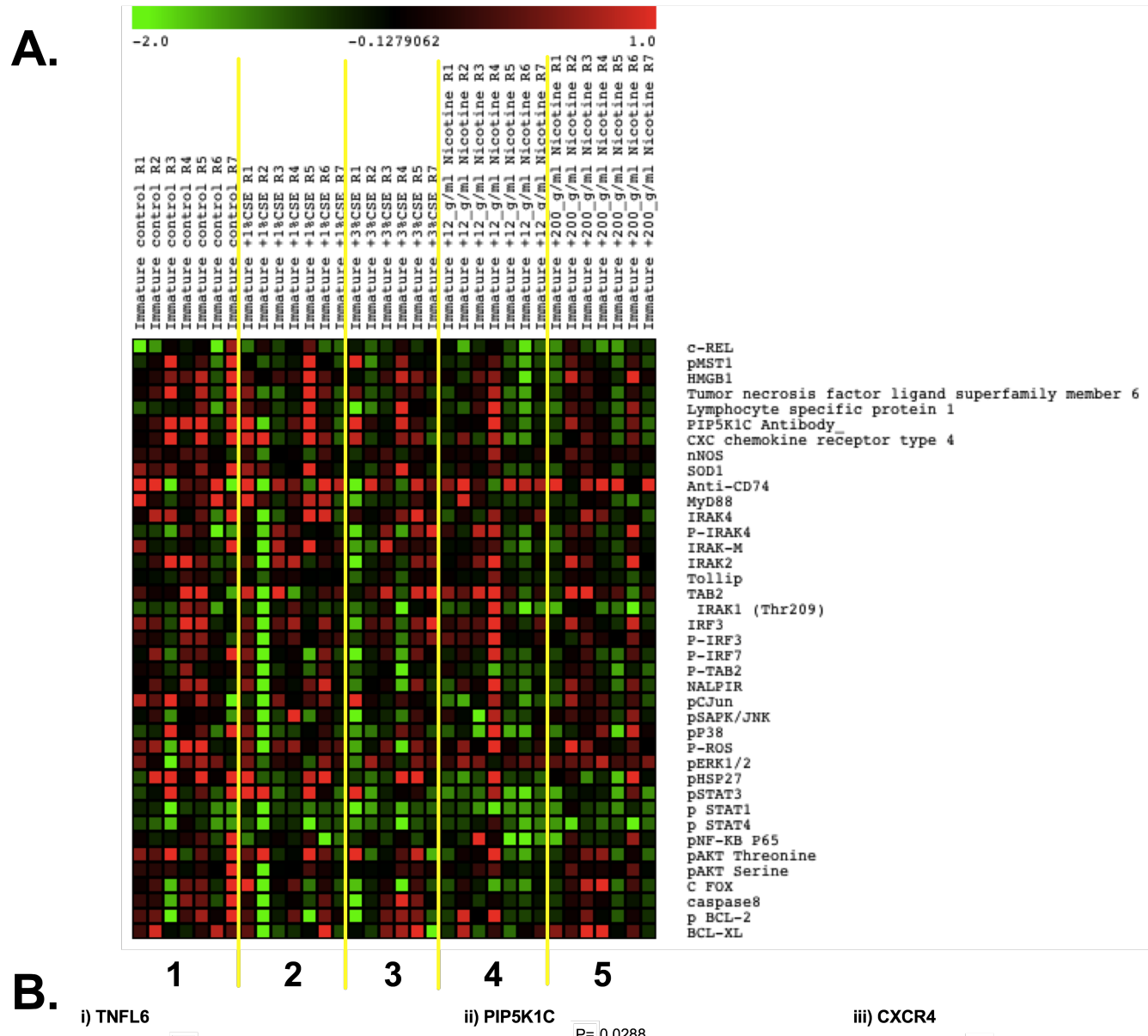

3
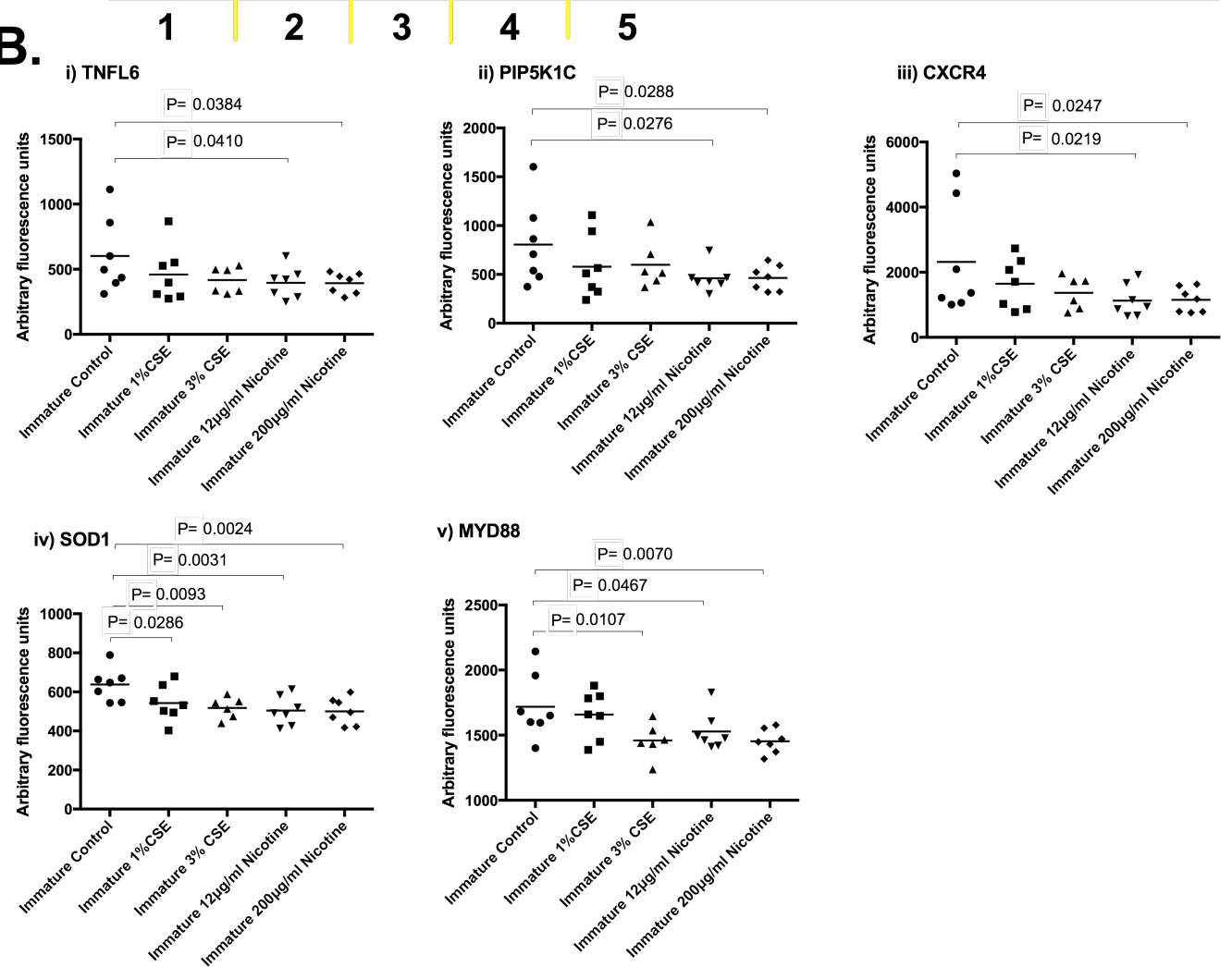

Supplementary figure 1. RPPA for immature human moDCs, with or without CSE or nicotine treatment. Each row shows expression of an individual protein in the lysates (indicated to the right). Bright red indicates high protein expression; bright green indicates low protein expression. Each individual column represents the levels of the proteins in the lysates of moDCs generated from PBMC-derived monocytes of different healthy donors (R1-R8). Each set of columns shows the results for DCs that were either untreated (1), or treated with $1 \% \operatorname{CSE}(2), 3 \% \operatorname{CSE}(3), 12 \mu \mathrm{g} / \mathrm{ml}$ nicotine (4) or $200 \mu \mathrm{g} / \mathrm{ml}$ nicotine (5). The analysis of 5 molecules is represented in scatter plots $(\mathrm{i}-\mathrm{v})$ showing the means of each group. Each dot represents the mean of three replicates of the same normal individual. $\mathrm{n}=7$ for all controls, $1 \% \mathrm{CSE}$, and $12 \mu \mathrm{g} / \mathrm{ml}$ and $200 \mu \mathrm{g} / \mathrm{ml}$ nicotine treatment, and $\mathrm{n}=6$ for $3 \%$ CSE-treated cells. 

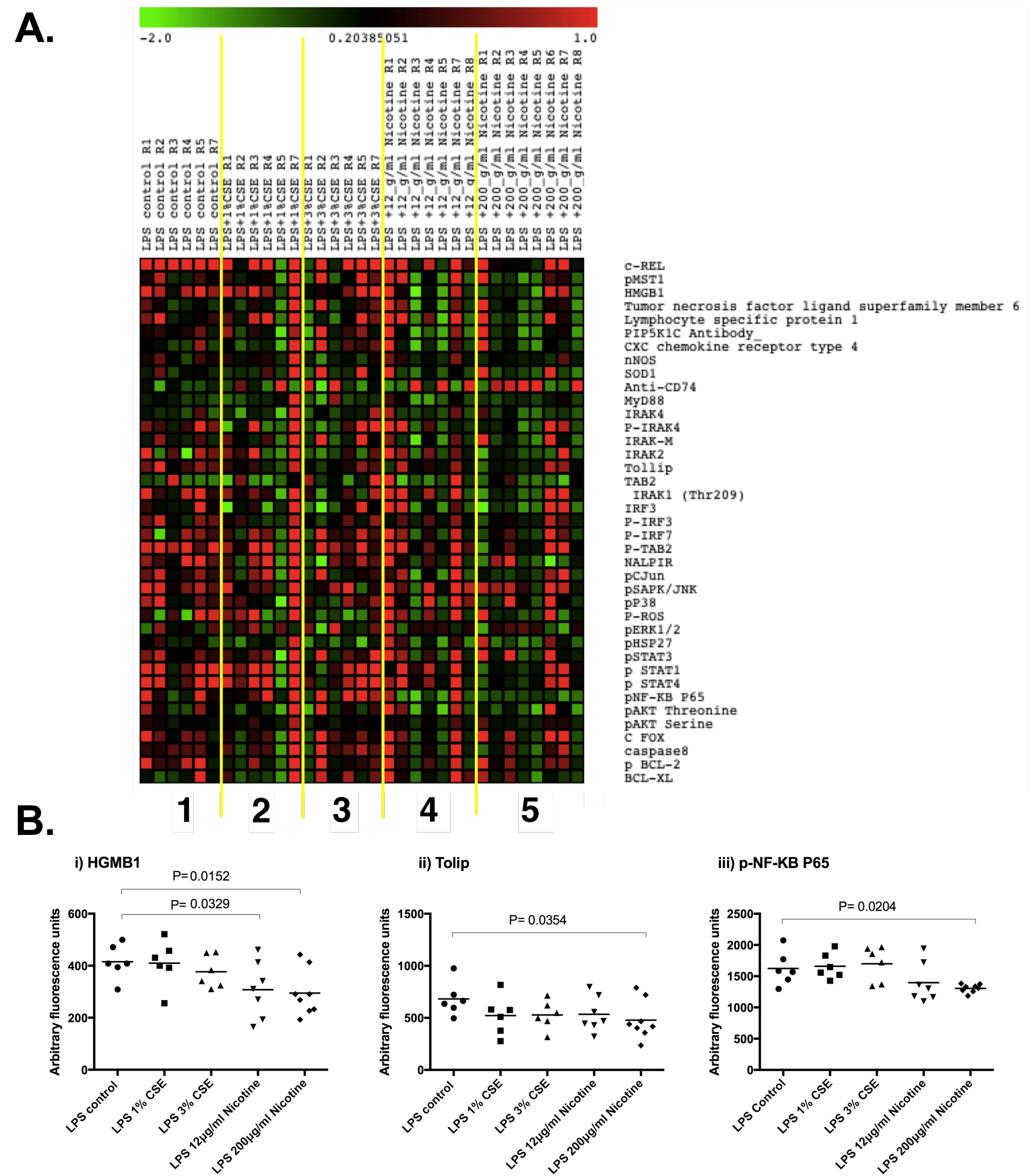

Supplementary figure 2. RPPA for LPS-matured human moDCs, with or without CSE or nicotine treatment. Each row shows expression of an individual protein in the lysates (indicated to the right). Bright red indicates high protein expression; bright green indicates low protein expression. Each individual column represents the levels of the proteins in the lysates of moDCs generated from PBMC-derived monocytes of different healthy donors (R1-R8). Each set of columns shows the results for DCs that were either untreated (1), or treated with $1 \%$ CSE (2), 3\% CSE (3), $12 \mu \mathrm{g} / \mathrm{ml}$ nicotine (4) or $200 \mu \mathrm{g} / \mathrm{ml}$ nicotine (5). The analysis of 3 molecules is represented in scatter plots (i - iii) showing the means of each group. Each dot represents the mean of three replicates of the same normal individual. $n=6$ for controls, $1 \%$ CSE- and 3\% CSE-treated cells; $\mathrm{n}=7$ for $12 \mu \mathrm{g} / \mathrm{ml}$ nicotine-treated cells and $\mathrm{n}=8$ for $200 \mu \mathrm{g} / \mathrm{ml}$ nicotine-treated cells. 